IZA DP No. 9646

Empirical Evidence on the Effectiveness of Social Public Procurement Policy: The Case of the Swiss Apprenticeship Training System

Mirjam Strupler Leiser

Stefan C. Wolter

January 2016 


\title{
Empirical Evidence on the Effectiveness of Social Public Procurement Policy: The Case of the Swiss Apprenticeship Training System
}

\author{
Mirjam Strupler Leiser \\ University of Bern \\ Stefan C. Wolter \\ University of Bern, \\ CESifo and IZA
}

Discussion Paper No. 9646

January 2016

IZA

P.O. Box 7240

53072 Bonn

Germany

Phone: +49-228-3894-0

Fax: +49-228-3894-180

E-mail: iza@iza.org

Any opinions expressed here are those of the author(s) and not those of IZA. Research published in this series may include views on policy, but the institute itself takes no institutional policy positions. The IZA research network is committed to the IZA Guiding Principles of Research Integrity.

The Institute for the Study of Labor (IZA) in Bonn is a local and virtual international research center and a place of communication between science, politics and business. IZA is an independent nonprofit organization supported by Deutsche Post Foundation. The center is associated with the University of Bonn and offers a stimulating research environment through its international network, workshops and conferences, data service, project support, research visits and doctoral program. IZA engages in (i) original and internationally competitive research in all fields of labor economics, (ii) development of policy concepts, and (iii) dissemination of research results and concepts to the interested public.

IZA Discussion Papers often represent preliminary work and are circulated to encourage discussion. Citation of such a paper should account for its provisional character. A revised version may be available directly from the author. 


\section{ABSTRACT \\ Empirical Evidence on the Effectiveness of Social Public Procurement Policy: The Case of the Swiss Apprenticeship Training System*}

In this paper we assess the effectiveness of a social public procurement policy in Switzerland that gives firms that train apprentices a preferential treatment. We estimate the effectiveness of this social procurement policy on a firm's training participation, training intensity, and training quality using information from a representative and large firm survey. The results show that the policy increases the number of training firms, and does not affect training quality negatively. However, the effect is limited in size, as only small firms and firms operating in sectors where public procurement represents a large share of the business, are affected positively.

JEL Classification: H32, I28, J08

Keywords: apprenticeship training, difference-in-differences, matching, public procurement policy, social public procurement

Corresponding author:

Stefan C. Wolter

Centre for Research in Economics of Education

Department of Economics

University of Bern

Schanzeneckstrasse 1

P.O. Box 8573

$\mathrm{CH}-3001$ Bern

Switzerland

E-mail: stefan.wolter@vwi.unibe.ch

\footnotetext{
* This study is based on two administrative surveys from the years 2004, and 2009. These surveys were financed by the Swiss Federal Office for Professional Education and Technology (OPET) with the assistance of the Swiss Federal Statistical Office. This research has been funded by the Swiss State Secretariat for Education, Research and Innovation (SERI) through its "Leading House on Economics of Education: Firm Behavior and Training Policies". We also thank Uschi Backes-Gellner, Eric Bettinger, Giorgio Brunello, Samuel Muehlemann, Paul Ryan and Ludger Woessmann for comments on an earlier version of this paper.
} 


\section{Introduction}

Social public procurement policies have long been used as an instrument to reach social goals (McCrudden, 2004 and 2007). Already in the $19^{\text {th }}$ century public contracts were linked to labor and employment standards in some countries like the US or in England. Later on governments attempted to use public contracting to reduce discrimination against women, racial minorities or disabled (McCrudden, 2004). A wide range of literature focusing mainly on programs in the US promoting labor market chances for minority groups shows that social public procurement policy can successfully reach the social goals set by the government (see for example Holzer and Neumark, 2000 for the effect of affirmative action programs in the US). However, the literature suggests that there are also potential drawbacks of the policy instrument like higher costs (Marion, 2009) or fraudulent firm behavior (Holzer and Neumark, 2000). We use the case of Switzerland, where public procurement policy aims to increase the number of training places provided by private firms, to analyze the effectiveness of social public procurement policy.

In Switzerland most public purchasers can nowadays account for training activities when awarding public contracts. Most of these regulations were introduced into public procurement laws in the last decade as a result of a shortage of training places. Promoting the supply of training places is particularly important because apprenticeship training is the most important educational pathway in Switzerland. Two-thirds of Swiss youths enter 2- to 4-year apprenticeship training programs after completing compulsory schooling, in which apprentices receive firmbased training and education at a vocational school. A well-functioning apprenticeship training 
system with a balanced demand and supply of training places is therefore crucial for the professional careers of young adults in Switzerland. However, for various reasons, such as demographic changes or the business cycle (see Muehlemann et al. 2009) imbalances are quite frequent. There has been a scarcity of training places in the 90 s and at the beginning of the last decade (e.g., Schweri und Mueller, 2007), whereas today, there is an over-supply of training positions. As a reaction to the shortage in training positions in the $90 \mathrm{~s}$, the government attempted to increase the supply of training places using for example public procurement policy. The aim of this social public procurement policy is to use a government's market power to achieve social goals such as increasing the number of apprenticeship training places.

In Switzerland, the most important public purchasers are cantons (similar to states in the US) and communities. Their contracts account for approximately 80 percent of public contracts in Switzerland (Felder and Podgorski, 2010). ${ }^{1}$ Cantons pass public procurement laws for public contracts at the canton and community level. Over the last two decades, nearly all cantons have modified these laws and allowed training firms to receive preferential treatment when awarding public contracts. $^{2}$

The present paper analyzes whether providing preferential treatment to training firms in the public procurement process increases the number of training firms and thus the number of training places and a firm's training intensity. In addition to the effect on training quantity, this

\footnotetext{
${ }^{1}$ Public expenditure for public building, goods and services accounted for about 25 percent of state expenditures and 8 percent of the GDP in 2003 (Felder and Podgorski, 2010).

2 By 2009, 22 of 26 cantons had introduced an "apprenticeship training" criterion in their legal frameworks.
} 
study investigates the effect of such a policy on training quality. Analyzing the effect on training quality is crucial to assess the suitability of the instrument, as only high-quality training provides young individuals with the necessary skills for a successful professional career.

To estimate the effect of the "apprenticeship training" criterion in public procurement laws on the number of training places, we first exploit that such a criterion exists in almost all cantons in 2009, and use cross-sectional survey data that includes subjective information on whether a firm is affected by the criterion. As robustness check we use the introduction of the criterion in a number of cantons between 2004 and 2009 to estimate the causal effect of the "apprenticeship training" criterion on a firm's training propensity.

The results reveal that allowing for the preferential treatment of training firms in the public procurement process increases the number of training firms and therefore the number of training places. However, the instrument only affects a very small number of firms in certain industries where public contracts play a substantial role. Moreover, as the instrument primarily changes the training behavior of small firms (i.e., at the extensive margin) and does not affect the number of apprentices within a training firm (i.e., at the intensive margin), the overall increase of apprenticeship training places is rather small. The results derived from the cross-sectional analysis are confirmed by the difference-in-differences analysis as the ranges of the effects strongly overlap. The result that training quality remains high for firms that offer apprenticeship places because of the public procurement policy is a promising finding for the apprenticeship training system and the policy instrument. 
The paper is structured as follows. Section 2 summarizes the literature and derives the research hypotheses. Section 3 describes the data. Section 4 explains the empirical strategy. Section 5 presents the results, and section 0 concludes.

\section{Literature and Hypotheses}

There exists so far no scientific study on the effect of public procurement policy on firms' training behavior. However, the instrument is related to other social public procurement policy instruments that have been researched before (see McCrudden 2004 and 2007). Empirical assessments of the impact of public procurement policies on social outcomes generally focus on the US, where such programs seek to increase labor market success for minorities. Several programs at the federal, state or local level have existed since the early 1970s. Most of them set aside or set percentage goals for public contracts for minority-owned firms (and subcontractors). Further programs compelled contractor firms to introduce antidiscrimination policies. Empirical findings suggest that the employment of black males rose more rapidly in contractor firms than non-contractor firms as a result of affirmative action in contracting and procurement (Ashenfelter and Heckman 1976, Chatterji et al. 2013, Goldstein and Smith 1976, Heckman and Payner 1989, Heckman and Wolpin 1976, Leonard 1984a, 1984b, 1990). ${ }^{3}$ Moreover, several empirical studies reveal an increase in the number of public contracts involving minority-owned firms as a result of affirmative action programs (e.g., Bates and Williams 1996).

\footnotetext{
${ }^{3}$ However, whether all of these studies truly capture the causal effects of affirmative action is a matter of dispute.
} 
Although a number of studies suggest that affirmative action policies ${ }^{4}$ are successful in achieving social goals, the policies also have disadvantages. Marion (2009), for example, presents evidence of higher costs in public works projects as a result of affirmative action. Moreover, the potential for fraudulent behavior cannot be excluded (Holzer and Neumark, 2000), and there is a risk that firms will be more likely to fail (Bates and Williams 1996), as the policy might create weak companies that are highly dependent on government contracts (Holzer and Neumark, 2000).

Besides the literature on social public procurement policy, the training literature serves for building hypotheses. The "apprenticeship training" criterion introduced in the most public procurement laws is also related to other policy instruments designed to provide incentives for firms to train apprentices, such as subsidies. The training literature provides empirical evidence demonstrating that subsidies influence the training decision and increase the number of training places (see, for example, Westergaard-Nielsen and Rasmussen, 1999 for Denmark or Muehlemann et al., 2007, for Switzerland). However, introducing subsidies to promote the creation of new training places may be a very expensive policy, if not only "new" training places but also "old" ones are subsidized, thereby creating windfall gains.

In summary, two strands of literature are considered for deriving hypotheses on the effectiveness of the "apprenticeship training" criterion in public procurement policy. Similar to affirmative action in contracting and procurement in the US, the "apprenticeship training" criterion in Swiss

\footnotetext{
${ }^{4}$ For an overview of the literature (theoretical and empirical) on affirmative action before 2000, see Holzer and Neumark (2000).
} 
public procurement policy is intended to advantage firms that act according to the goals established by the government (increasing the number of training places). Although the designs and goals of the policies differ, the results from studies on the US suggest that public procurement policies can change firm behavior. However, evidence on non-training firms in Switzerland suggests that the effect size of such a policy may be rather small because of the significant potential net training costs for non-training firms. While training firms are more likely to be awarded a public works contract and can charge higher prices ${ }^{5}$ than non-training firms, these expected benefits must outweigh the net costs of training to change a firm's training behavior. Therefore, the policy will only be successful if a sufficient number of such non-training firms exist.

A firm's training propensity increases strongly in firm size. Large firms train more often because they may benefit more from training: First, the probability that a firm employs workers in at least one training occupation increases in firm size. Second, small firms are often specialized, which makes it more difficult (and thus costly) to provide the apprentice with the required training content and simultaneously reduces the opportunity to allocate productive tasks to the apprentice. However, large firms have a broader range of tasks for apprentices and can therefore better integrate them into the production process, where apprentices create benefits for firms. Third, larger firms with numerous employees need to fill more vacancies than small firms. Blatter et al. (2012 \& 2015) demonstrate that hiring costs increase in the number of hires. It is therefore

\footnotetext{
${ }^{5}$ Several court decisions (for example, VB.2002.00255 from the Canton of Zurich) fixed the maximum weight given to apprenticeship training below ten percent.
} 
beneficial for large firms to diversify their recruitment strategies and use training as a recruitment device to satisfy their future need for skilled workers.

Therefore, we can assume that the inclusion of the criterion in legal frameworks increases the probability that training firms will be treated preferentially in the public procurement process, and as a consequence, the policy creates training incentives at the margin, affecting only a small number of small-sized, non-training firms with positive but relatively low (expected) net training costs. Furthermore, because public contracts should be more prevalent in certain industries, we expect heterogeneous effects across industries.

Training firms could also create additional apprenticeship training places if the policy were able to incentivize training firms to increase the number of training places. The requirements for the preferential treatment of training firms in many cantons, however, are applied with respect to firm size and according to the customary number of apprentices in the industry. Furthermore, the majority of Swiss training firms are small firms with one or two apprentices. Therefore, we assume that the policy does not increase the number of training places in training firms.

In addition to the effect on training quantity, this study provides an analysis of the effect on training quality. In the context of training, quality aspects are very important, as only high-quality training provides young individuals with the skills required for a successful professional career. There could be a trade-off between creating additional training places and training quality, as firms that only provide training to obtain preferential treatment in the public procurement process 
might be less prone to provide high-quality training. Nevertheless, a decrease in quality may be unlikely due to legal constraints and the reputational considerations of training firms (Wolter and Ryan, 2011). Therefore, we assume that the public procurement policy has no negative effect on training quality.

\section{Data}

To analyze the effect of a public procurement policy on a firm's training behavior, this paper uses a representative firm-level cross-sectional dataset that was collected in 2009 to analyze the costs and benefits of apprenticeship training in Switzerland. To account for the stratified sampling the results presented in this article are weighted by sampling weights. ${ }^{6}$ For the robustness check, we additionally use the same type of dataset collected in 2004. The survey on training and nontraining firms collected in 2009 comprises information on the existence of the "apprenticeship training" criterion for public contracts in the firm's field of activity (canton, industry). As a robustness check we exploit a natural variation between cantons in Switzerland and estimate a difference-in-differences model. The cost-benefit survey is a representative national survey and comprises information on 2,580 training firms and 10,116 non-training firms in 2009 and 2,413 training firms and 1,863 non training firms in 2004. In addition to detailed information on costs and benefits of apprenticeship training, the data contain comprehensive information on firm characteristics and training behavior. Moreover, in 2009, firms indicated in the survey whether in

\footnotetext{
${ }^{6}$ For more details on the sample design and the calculation of weights were provided by the Federal Statistical Office.
} 
their field of economic activity (canton, industry), public purchasers apply an "apprenticeship training" criterion for the award of the contract.

There are a number of reasons why we use a subjective assessment of firms as an indication whether the firm is affected by the policy rather than an objective measure: Firstly, in accordance with international laws (WTO-GPA), the criterion can only be applied to contracts below a certain contract volume threshold. Large projects above this threshold for which international firms compete for the contract are excluded, as foreign firms are not allowed to be discriminated against Swiss firms. Therefore, even if the law contains the criterion and even if we know that the firm operates in a business where public contracts are relevant, we would not know whether a firm is regularly or only hardly ever affected by the criterion. Secondly, most cantonal procurement laws contain a non-exhaustive list of potential criteria (additional to the price) for the reward of public contracts. Training apprentices is just one of these potential criteria and public purchasers are free to apply them. ${ }^{7}$ Responses to a quick survey we made in several cantons regarding the application of the criterion revealed, that many cantons do not consider the criterion to be mandatory and apply it in a rather discrete manner. For these reasons we cannot identify an objective measure for the use of the criterion and have to rely on the subjective assessment of the situation in their canton and industry by the firms.

\footnotetext{
${ }^{7}$ Even public purchasers in cantons without such a criterion in there laws could theoretically apply the criterion for certain contracts.
} 
Using the subjective information of firms on the use of the criterion has of course the disadvantage that the answer may be biased by the experience of firms with the process of awarding public contracts. Firms that never compete for public contracts may have a tendency to respond "no" to the question not because the criterion is not applied but rather because of their ignorance of the process. Conversely, if firms compete frequently for public contracts, they have a higher probability to learn that the criterion exists and is applied. Despite the bias that this might create in the "yes" and "no" answers, we do not see a problem for our analysis. Although the answer of the firm is a combination of the likelihood that the criterion is used by the public authorities and the inclination of firms to compete for public contracts, there is no reason to assume that the decision to train apprentices has a causal impact on the likelihood to apply later for public contracts. Firms choose their field of economic activity first and this influences the likelihood that public procurement is relevant for them or not and only depending on this the question becomes relevant whether apprenticeship training has an impact on the probability of winning a public contract. There are certainly economic sectors where apprenticeship training and public procurement are - for various reasons - positively correlated and that is the reason why we use a matching strategy that compares the training probability of firms that answer differently to the criterion question but operate in the same economic sector (see also paragraph 4).

As the focus of this analysis is on the impact of the "apprenticeship training" criterion on private firms, public institutions are excluded from the dataset. Moreover, only non-training firms that 
are theoretically capable of offering training are considered in the analysis. ${ }^{8}$ Furthermore, mainly export-oriented firms (2.6\% of all firms in our sample) are excluded as they are assumed not to compete for public contracts in Switzerland.

After the exclusion of public firms, firms that theoretically cannot train, and export-oriented firms a total of 6,813 firms remain in the sample for the 2009 survey. Among those firms, 17 percent indicated that there exists a criterion "apprenticeship training" in their field of activity (yes or partially). In contrast, 68 percent of the firms are not at all affected by such a criterion.

Table 1 shows that the share of firms indicating that such a criterion exists in their field of activity is larger for training firms than for non-training firms.

Table 1: "Apprenticeship training" criterion in public procurement, full sample Answer Total share Share training firms Share non-training

\begin{tabular}{lccc} 
& \multicolumn{2}{c}{ firms } \\
\hline Yes & $6.6 \%$ & $12.6 \%$ & $2.8 \%$ \\
Partially & $10.5 \%$ & $16.7 \%$ & $6.6 \%$ \\
No & $67.6 \%$ & $64.0 \%$ & $69.9 \%$ \\
No answer & $15.2 \%$ & $6.6 \%$ & $20.7 \%$ \\
\hline Observations & 6,813 & 1,676 & 5,137
\end{tabular}

Question: Are training firms in your field of activity (canton, industry) treated preferentially when applying for public works or services?

The large number of firms (two-thirds) not being affected by the policy combined with the fact that almost all cantons knew such an "apprenticeship training" criterion by 2009 indicates that public procurement policy affects only a small fraction of firms in particular industries. Public

8 Firms that theoretically cannot provide training are generally very small and specialized. Their size and specialization prevent them from training because they cannot provide the apprentice with all necessary training content or do not employ workers in any training occupation. 
contracts are typically concentrated in certain industries, such as construction, while public contracts are almost non-existent in other industries. We choose to do all analyses for the full sample as well as for a restricted sample where we only considered economic sectors where at least a minimal number of firms responded that the criterion was applied (at least $10 \%$ of the firms in the economic sector, measured on a two-digit industry level or at least $5 \%$ if combined $20 \%$ of the firms responded either "yes" or "partially yes"). These industries are manufacturing of wood, wicker, cork products and of fabricated metal products and of electrical equipment, energy supply, sewerage and waste management, recycling, construction of building, civil engineering other construction activities, architectural and engineering activities as well as insurance, reinsurance, pension funding. Thus, 1,744 firms remain for this further analysis: 48 percent of these firms indicated that public purchasers in their field of activity consider apprenticeship training when awarding the contract (see Table 2).

Table 2: Criterion apprenticeship training in public procurement; industries with public contracts

$\begin{array}{lccc}\text { Answer } & \text { Total share } & \text { Share training firms } & \begin{array}{c}\text { Share non-training } \\ \text { firms }\end{array} \\ & & & 8.6 \% \\ \text { Yes } & 20.7 \% & 31.4 \% & 19.5 \% \\ \text { Partially } & 27.2 \% & 34.1 \% & 53.9 \% \\ \text { No } & 41.7 \% & 30.8 \% & 18.0 \% \\ \text { No answer } & 10.4 \% & 3.7 \% & 1,148\end{array}$

Question: Are training firms in your field of activity (canton, industry) treated preferentially when applying for public works or services? 
The descriptive statistics in Table 1 and Table 2 suggest that there exists a positive relationship between the "apprenticeship training" criterion in public procurement and the training probability.

In addition to estimating the effect of public procurement policy on the number of training places (quantity), the cost-benefit data makes it possible to investigate potential effects on training quality. ${ }^{9}$ Training quality is multidimensional and thus difficult to measure. The advantage of the present data is that they contain comprehensive information on apprenticeship training within the firm and comprise two indicators of training quality. The first indicator is the average number of weekly training hours per apprentice, and the second is the relative productivity of the apprentice in the last year of training, compared to the productivity of the average skilled worker in the same trade within the firm. Training hours indicate how many hours instructors and other workers in the firms invest in training the apprentice. A negative effect on training hours implies that the additionally created training places provide less training and therefore provide training of belowaverage quality. The second quality measure, the relative productivity of the apprentice in the last year of training, is an output-oriented measure and indicates how well apprentices are prepared for their career as skilled workers after receiving training. A lower value for the relative productivity due to the public procurement policy would indicate that apprentices receiving training as a result of such a policy are not as well prepared for their future professional careers

\footnotetext{
9 For the analysis on training quality we use only firms that answer the question on the existence of an "apprenticeship training" criterion in public procurement with "yes" or "no". However, results remain qualitatively the same when other firms are considered, too.
} 
than other apprentices. Descriptive statistics for the quality measures are provided in Table 9 in the Appendix.

\section{Empirical Strategy}

To calculate the average treatment effect and to control for differences between firms affected and not affected by the criterion, this paper adopts a matching strategy. The applied exact matching (Abadie et al., 2004) ${ }^{10}$ ensures that only firms with similar (observable) characteristics are compared. The effect of the treatment can be defined in a potential outcome framework (Rubin, 1974). $Y_{i}(1)$ denotes the outcome (training behavior or training quality) of firm $i$ when exposed to the treatment, and $Y_{i}(0)$ is the outcome for firm $i$ when not exposed to the treatment. $Y_{i}$ is equal to one for training firms and zero for non-training firms, for the training quality $Y_{i}$ denotes to the quality measures training hours or relative productivity of the apprentice in the last year of training. The treatment $D_{i}$ represents preferential treatment of training firms in the public procurement process. $D_{i}$ takes the value one if an "apprenticeship training" criterion exists in the firm's field of activity and zero otherwise. As never both, $Y_{i}(1)$ and $Y_{i}(0)$ are observable for one firm, the unobserved potential outcome for each firm $i$ has to be estimated.

\footnotetext{
${ }^{10}$ We use the stata program nnmatch for nearest neighbor matching with the option "exact" ensuring that a vast majority of the matched firms have the same characteristics in terms of firms size category and industry.
} 
Let the observed outcome $Y_{i}$ be denoted by:

$$
Y_{i}=Y_{i}\left(D_{i}\right)= \begin{cases}Y_{i}(0) & \text { if } D_{i}=0 \\ Y_{i}(1) & \text { if } D_{i}=1\end{cases}
$$

For the estimation of the unobserved potential outcome (counterfactual), the matching method imputes the missing counterfactual by averaging outcomes of similar firms (with the same observable characteristics) in the sample but who were exposed to the other treatment. To ensure that the estimator identifies a causal and consistent treatment effect two assumptions have to hold: The first underlying assumption for an unbiased estimate of the causal effect is that there are no unobservables that affect the training decision and the choice of the firm to be active in an industry and canton where training firms are treated preferentially in the public procurement process at the same time (unconfoundness).

$$
Y_{i}(1), Y_{i}(0) \perp D_{i} \mid X=x
$$

where $\mathrm{X}$ represents a set of observable characteristics. This unconfoundness assumption would be violated if firms would first choose to train or not and then, as a function of the first decision, choose their field of activity and the canton of location. As apprenticeship training is never the core business of a firm we can safely assume that firms first choose their field of activity and make their location decision and subsequently make their training decision. The location decision is independent of the existence of the training criterion in cantonal laws, and therefore, the 
treatment is random for firms with the same observables and the unconfoundness assumption holds.

The second assumption

$$
0<P\left(D_{i}=1 \mid X\right)<1
$$

holds when the probability of assignment is restricted between zero and one (Abadie et al., 2004). This assumption holds for the sample of firms in industries with a considerable amount of public contracts, as there are enough firms with similar characteristics that are (not) affected by preferential treatment of training firms in public contracting.

For the unobserved potential outcome the simple matching estimator (Abadie et al, 2004) is:

$$
\begin{array}{r}
\widehat{Y}_{l}(0)=\left\{\begin{array}{r}
Y_{i} \text { if } D_{i}=0 \\
\frac{1}{\# \mathcal{T}_{M}(i)} \sum_{l \in \mathcal{T}_{M}(i)} Y_{l} \text { if } D_{i}=1
\end{array}\right. \\
\widehat{Y}_{l}(1)=\left\{\begin{array}{r}
\frac{1}{\# \mathcal{T}_{M}(i)} \sum_{l \in \mathcal{T}_{M}(i)} Y_{l} \text { if } D_{i}=0 \\
Y_{i} \text { if } D_{i}=1
\end{array}\right.
\end{array}
$$

where $\mathcal{T}_{M}(i)$ denotes the set of indices for the matches for a firm $i$ and $\# \mathcal{T}_{M}(i)$ the number of elements of $\mathcal{T}_{M}(i) . l$ represents the observations of the control group. 
The matching estimator for the average treatment effect on the treated is then: ${ }^{11}$

$$
A T T=\frac{1}{N_{1}} \sum_{i: D_{i}=1}\left\{Y_{i}-\widehat{Y}_{l}(0)\right\}
$$

\section{Results}

Table 3 shows the average treatment effects on the treated (ATT) for all firms in our sample. The first coefficient represents the effect for firms that are affected by the criterion in their whole field of activity compared to those firms not being affected. The second line presents the ATT for firms partially affected by the criterion compared to not affected firms. This effect is smaller compared to the precedent effect. Thus, as expected, the criterion creates more incentives for firms being more heavily affected by the policy. The finding, that not only firms that responded "yes" in the survey train more than firms that see themselves not affected at all but also that the impact - while positive - is smaller for firms that feel only partially affected, is an indication, that the effect of the public procurement instrument on training behavior is more than just a spurious correlation. Finally, the last line in Table 3 represents the effect for firms partially and entirely affected by the procurement policy compared to firms that are not affected. The ATT show, that all effects are significantly positive and reveal an effect of about 20 to 28 percentage points.

\footnotetext{
${ }^{11}$ For additional details see Abadie et al. (2004)
} 
Table 3: Bandwidth for the effect of the "apprenticeship training" criterion on training probability

\begin{tabular}{llcc} 
& Coefficient & Std. Error & N \\
\hline "yes" to "no" firms & $0.280^{* * *}$ & 0.0349 & 4,970 \\
"partially" to "no" firms & $0.198^{* * *}$ & 0.0277 & 5,279 \\
"yes" and "partially" to "no" firms & $0.230^{* * *}$ & 0.0253 & 5,670 \\
\hline
\end{tabular}

Note: Matching variables: Industry (two-digit-level) and firm size. Robust standard errors.

"Yes" firms: firms that are affected by the policy in their whole field of activity

"Partially" firms: firms that are in some fields of activity affected by the policy

Table 4 presents the results (ATT) for the reduced sample of firms operating in industries with public contracts. Furthermore, to count for non-response different firms are considered as treated firms. The results show bandwidths for the effect as different answering scenarios are assumed for the non-responses. ${ }^{12}$ The results show that the ATT is positive for all scenarios. The effect is larger for firms that are in all their fields of activities affected by the policy ("yes" firms) compared to firms that are only in parts of their activities affected by the criterion ("partially" firms). For all firms affected by the policy ("yes" and "partially" firms), the bandwidth of the effects on their training probability is between 19 to 32 percentage points. ${ }^{13}$

Table 4: Bandwidth for the effect of the "apprenticeship training" criterion on training probability

\begin{tabular}{lcccc} 
& \multicolumn{2}{c}{ effect } & \multicolumn{2}{c}{$95 \%$-confidence interval } \\
& lower bound & upper bound & & \\
\hline "yes" firms & 0.15 & 0.37 & 0.08 & 0.45 \\
"partially" firms & 0.11 & 0.28 & 0.04 & 0.35 \\
"yes" and "partially" firms & 0.19 & 0.32 & 0.13 & 0.38 \\
\hline
\end{tabular}

Note: Matching variables: Industry (two-digit-level) and firm size. Estimates for different answering scenarios for "no answer" firms. Robust standard errors.

"Yes" firms: firms that are affected by the policy in their whole field of activity

"Partially" firms: firms that are in some fields of activity affected by the policy

\footnotetext{
${ }^{12}$ Non-responses are once considered as firms affected, once partially affected and once not affected by the policy.

${ }^{13}$ The 95\%-percent confidence intervals show that estimated effects are significantly higher than zero.
} 
The effect sizes are comparable between the full and the reduced sample, which is not surprising, as the presented effect is an average treatment effect on the treated and by definition the majority of treated firms operate in industries with public contracts. The increase in training probability seems to be very high. However, one has to bear in mind that this effect considers only a very small fraction of firms in industries where public contracts are very important. Therefore, the effect size does not represent a large overall increase of training places. The present data does not allow identifying the effect on the whole apprenticeship market. However, we know that from all firms answering the question about the "apprenticeship training" criterion in our survey, only about 20 percent were at least partially affected by the policy. 80 percent of the firms were not affected by the policy. Weighing the average treatment effect on the treated (ATT) presented in Table 4 for these 20 percent reveals an overall effect on training probability of about 3.8 to 6.4 percentage points. However, the number of training firms does not represent the number of training places. The number of newly created training places primarily depends on the size of the incentivized firms. If additional training places are created predominantly in small firms, then an additional training firm typically only provides one additional training position. If, however, large firms were more likely to be incentivized by such a policy, then an additional training firm could create more than one additional training position. Moreover, additional training places could be created in training firms, increasing the number of apprentices. Table 5 shows average treatment effects on the treated by firm size (for the reduced sample). The results in Table 5 demonstrate that only small and medium firms with less than 50 employees are affected by the instrument, whereas large firms are not incentivized by the criterion. 
Table 5: The effect of the "apprenticeship training" criterion on the training probability by firm size

\begin{tabular}{lccc}
$\begin{array}{l}\text { Firm size } \\
\text { (Number of employees) }\end{array}$ & Coefficient & Standard error & Observations \\
\hline $1-9$ & 0.38 & $0.054^{* * * *}$ & 647 \\
$10-49$ & 0.35 & $0.078^{* * *}$ & 289 \\
$50-99$ & 0.09 & 0.090 & 101 \\
$>100$ & 0.16 & 0.113 & 72
\end{tabular}

Note: Matching variables: Industry (two-digit-level). ATT for firms affected by the "apprenticeship training" criterion in the public procurement process compared to those than are unaffected. Missing values and firms partially affected are excluded. Robust standard errors.

Significance level: ${ }^{*} p<.1,{ }^{* *} p<.05,{ }^{* * *} p<.01$

This result is in line with our hypotheses; large firms have higher training probabilities independent of the existence of the criterion as large firms train apprentices to a larger extent for investment reasons, i.e., to retain apprentices as skilled workers after training, they are less responsive to additional monetary incentives than smaller firms that predominantly have a production-oriented training motive (i.e., training creates a net benefit by the end of the program). Moreover, the probability of employing workers in at least one training occupation increases in firm size. Therefore, larger firms have more productive tasks for apprentices and can better integrate them into their production process, where apprentices create benefits for firms. Conversely, small and specialized firms face greater difficulties in providing the required training content and are less able to allocate productive tasks to an apprentice.

Besides the effect at the extensive margin, the criterion could also affect the number of apprentices in training firms. Some cantons consider the number of apprentices as a function of the total number of workers in the firm and the industry standard number of apprentices, when applying the "apprenticeship training" criterion. However, for the majority of rather small firms, 
one apprentice is standard. The results in Table 6, therefore, show no effect of the criterion and are in line with the hypotheses that training intensity is not affected by the criterion. ${ }^{14}$

Table 6: Effect of the "apprenticeship training" criterion on training intensity; training firms only

$$
\text { Coefficient Standard error Observations }
$$

\begin{tabular}{llll}
\hline Training intensity & -0.15 & 0.324 & 379
\end{tabular}

Note: Matching variables: Industry (two-digit) and firm size. ATT for firms affected by the "apprenticeship training" criterion in the public procurement process compared to those than are unaffected. Missing values and firms partially affected are excluded. Robust standard errors. Significance level: ${ }^{*} p<.1,{ }^{* * *} p<.05,{ }^{* * * *} p<.01$

The results demonstrate that public procurement policy can create additional training places by incentivizing non-training firms to train. However, only small firms operating in industries with public contracts are affected by the policy. Although the policy is successful in creating training incentives for these particular firms, the overall effect on the number of training firms is limited. A back-on-the-envelope calculation of the effect of the criterion on the apprenticeship market ${ }^{15}$, which is the main target of politicians claiming such a policy, shows an increase of about 2 to 4.9 percent in the number of training places as a result of this public procurement policy.

For a comprehensive assessment of the instrument, it is crucial to analyze the effect on training quality. The instrument is only successful if the additional training places provide sufficiently

\footnotetext{
${ }^{14}$ As an additional analysis we also checked, whether the positive effect of the criterion on the training probability provokes a crowding out of other training measures. Our analyses shows that firms that report to be affected by the criterion do not report less continuous training for the personnel compared to firms that report not being affected (results can be obtained from the authors on request).

15 The present data does not allow estimating the effect on the number of apprenticeship training places. The backon-the-envelope calculation assumes that every additional training firm creates one additional training place and compares this number to the total number of training places in 2009 in Switzerland.
} 
high training quality. Table 7 reports the effects of the instrument on training quality. ${ }^{16}$ In line with our hypotheses we cannot find any trade-off between training quantity and training quality, as there are no differences in the number of training hours and the relative productivity of apprentices in the last year of training between firms that are affected and those that are not affected by the criterion.

Table 7: Effect of the "apprenticeship training" criterion on training quality; training firms only

\begin{tabular}{|c|c|c|c|}
\hline & Coefficient & Standard error & Observations \\
\hline Number of training hours ${ }^{17}$ & 0.03 & 0.22 & 379 \\
\hline Relative productivity in the last year of training & -1.01 & 1.81 & 379 \\
\hline
\end{tabular}

\section{Robustness check}

The results elicited from the cross-section analysis reveal a positive effect of the social public procurement policy on training probability. However, whether these effects are truly causal or the result of unobserved heterogeneity between treated and non-treated firms cannot be answered with a cross-sectional comparison alone. Therefore, we additionally estimate the effect of this policy on training behavior exploiting that some cantons mentioned in their legal frameworks the possibility to treat training firms preferentially before 2004, while other cantons only introduced

\footnotetext{
${ }^{16}$ Firms partially affected by the policy are excluded. However, the results do not change qualitatively when accounting for these firms.

${ }^{17}$ Descriptives for the quality measures can be found in the appendix.
} 
the "apprenticeship training" criterion between 2004 and 2009. ${ }^{18,19}$ Before 2004, eleven cantons ${ }^{20}$ already introduced regulations that allowed public purchasers to treat training firms preferentially. Two of them ${ }^{21}$ introduced the criterion between 2000 and 2004, while all others did so before 2000. To estimate the causal effect, we use the introduction of such a criterion in ten cantons between 2004 and 2008. ${ }^{22}$ Apprentices in Switzerland are typically recruited at least half a year before the beginning of the training in August. ${ }^{23}$ Therefore, the introduction of the criterion in 2004 does not affect the number of training places in 2004 but only in 2005. Four cantons had no such regulations even by 2009 and are consequently dropped from the analysis. ${ }^{24}$ 37 percent of the private firms that theoretically can train participated in training in 2004 in cantons knowing the "apprenticeship training" criterion already before 2004 ("no change" cantons). In cantons not mentioning such a criterion in their public procurement laws the according share was 38 percent. For both groups training probability increased between 2004 and 2009, however, with 8 percentage points compared to 3 percentage points this increase was much

\footnotetext{
${ }^{18}$ Unfortunately, the administrative records of the Swiss establishment register are not updated annually. As the census years do not fit well with the introduction of the "apprenticeship training" criterion we therefore have to rely on the survey data from 2004 and 2009.

${ }^{19}$ A crucial assumption for the identification of a causal effect of the treatment is a common trend before the treatment. Unfortunately, we can neither exclude nor confirm a common trend, because no data exist before 2000 to analyze a common trend.

${ }^{20}$ These cantons are Aargau, Appenzell Innerrhoden, Berne, Fribourg, Geneva, Glarus, Jura, Neuchâtel, St. Gallen, Vaud, Zurich.

${ }^{21}$ Only two rather small Cantons (Appenzell Innerrhoden and Neuchâtel) introduced the criterion between 2000 and 2004.

${ }^{22}$ Appenzell Ausserrhoden, Grisons, Luzern, Obwalden, Schaffhausen, Solothurn, Schwyz, Thurgau, Uri, Zug.

${ }^{23}$ For example by April 201272 percent of the potential apprentices already had a training contract signed for an apprenticeship starting in August 2012. Source: SBFI Lehrstellenbarometer, http://www.sbfi.admin.ch/berufsbildung/01587/01607/index.html?lang=de, 27.5.2013

${ }^{24}$ The dropped cantons are Basel-Stadt, Basel-Land, Valais and Nidwalden. About 10 percent of the observations are dropped due to the exclusion of these cantons. Firms from these cantons are not a considered as a meaningful control group as these cantons are very particular and the number of observations is small.
} 
stronger in cantons introducing the "apprenticeship training" criterion between 2004 and $2009 .^{25}$ The considerable increase in training probability in cantons that introduced the criterion between 2004 and 2009 suggests that this policy instrument was very successful. However, the increase in the share of training firms in cantons with a change in their public procurement laws could be the result of reasons other than a change in public procurement policy. Therefore, to control for trends in training conditions, this section compares firms in cantons with and without a legislative change and applies a difference-in-differences strategy. The treatment group consists of all firms in cantons with changes in the relevant legislation between 2004 and 2009. The control group comprises firms in cantons that introduced the "apprenticeship training" criterion in their legal frameworks before 2004. The two years of data (2004 and 2009) allow controlling for systematic time-invariant differences between control and treatment group.

The effect is estimated with a linear regression model (for more details see for example Angrist and Pischke, 2009):

$$
Y_{i c t}=\beta_{0}+\beta_{2} D 09_{t}+\beta_{3} \text { Change }_{c}+\delta\left(D 09_{t} \cdot \text { Change }_{c}\right)+X^{\prime}{ }_{i s t} \beta+\varepsilon_{i s t}
$$

where $D 09_{t}$ denotes a dummy for the post-treatment period (cross-section 2009) and Change $e_{c}$ is a dummy that takes the value one for firms in cantons with changes in procurement legislation and

\footnotetext{
${ }^{25}$ For the control group of firms in cantons knowing the criterion before 2004 the share of training firms increased from 37 to 40 percent.
} 
zero otherwise. The vector $\mathrm{X}$ represents firm characteristics (firm size, language region, occupation, industry, and canton).

Table 8 presents the results of the difference-in-differences (see equation 7) estimation exploiting the fact that some cantons introduced the "apprenticeship training" criterion in their legal frameworks between 2004 and 2009, whereas the criterion was already in force in another group of cantons. The results suggest that the "apprenticeship training" criterion has a positive effect on training probability, however, estimation is not very precise and therefore the estimate no statistically significant. The results suggest that the introduction of the criterion increases training probability by 5.8 percentage points.

Table 8: The effect of the introduction of the criterion "apprenticeship training" on the number of training firms (DiD)

\begin{tabular}{|c|c|c|c|c|c|}
\hline $\begin{array}{l}\text { Dependent Variable: } \\
\text { Training probability }\end{array}$ & (1) & (2) & $\begin{array}{l}L P M \\
(3)\end{array}$ & (4) & $(5)$ \\
\hline Treatment (D09 x change) & $\begin{array}{c}0.057 \\
(0.039)\end{array}$ & $\begin{array}{c}0.058 \\
(0.037)\end{array}$ & $\begin{array}{c}0.065 \\
(0.036)^{*}\end{array}$ & $\begin{array}{c}0.067 \\
(0.036)^{*}\end{array}$ & $\begin{array}{c}0.058 \\
(0.036)\end{array}$ \\
\hline $\begin{array}{l}\text { Post treatment period } \\
\text { (year 2009) }\end{array}$ & $\begin{array}{c}0.025 \\
(0.021)\end{array}$ & $\begin{array}{c}0.016 \\
(0.020)\end{array}$ & $\begin{array}{c}0.006 \\
(0.020)\end{array}$ & $\begin{array}{c}0.004 \\
(0.020)\end{array}$ & $\begin{array}{c}0.006 \\
(0.020)\end{array}$ \\
\hline $\begin{array}{l}\text { Cantons introducing this } \\
\text { legislation after } 2004 \text { (change) }\end{array}$ & $\begin{array}{c}0.009 \\
(0.030)\end{array}$ & $\begin{array}{c}0.002 \\
(0.029)\end{array}$ & $\begin{array}{l}-0.002 \\
(0.029)\end{array}$ & $\begin{array}{l}-0.002 \\
(0.029)\end{array}$ & $\begin{array}{c}-0.103 \\
(0.059)^{*}\end{array}$ \\
\hline Controls & & & & & \\
\hline Occupation & No & Yes & Yes & Yes & Yes \\
\hline Industry & No & No & Yes & Yes & Yes \\
\hline Firm size (and firm size sqr.) & No & No & No & Yes & Yes \\
\hline Canton & No & No & No & No & Yes \\
\hline Constant & $\begin{array}{c}0.372 \\
(0.015)^{* * *} \\
\end{array}$ & $\begin{array}{c}0.252 \\
(0.021)^{* * *}\end{array}$ & $\begin{array}{c}0.355 \\
(0.035) * * *\end{array}$ & $\begin{array}{c}0.352 \\
(0.035) * * *\end{array}$ & $\begin{array}{c}0.365 \\
(0.042)^{* * *}\end{array}$ \\
\hline Observations & 9,052 & 9,052 & 9,052 & 9,052 & 9,052 \\
\hline $\mathrm{R}^{2}$ & 0.003 & 0.078 & 0.105 & 0.115 & 0.130 \\
\hline
\end{tabular}


This estimate remains relatively stable across all specifications and suggests that public purchasers use the criterion in contracting. The estimate lies within the range of the effect size identified in the first part of this paper and therefore confirms the results obtained by analyzing the cross-sectional data.

The effect identified in Table 8 is not estimated very precisely. There are several reasons for this: First, the difference-in-differences estimator identifies the effect of the introduction of the "apprenticeship training" criterion and not its application, whereas the result from the crosssection represents the effect of the application of the criterion in the majority of cantons. Second, it may not be the case that all public purchasers apply the criterion within a canton. Furthermore, cantonal borders do not perfectly reflect procurement markets. Firms can also apply for public works contracts outside their canton of residence. The existence of the criterion only increases the probability that a firm in the given canton is affected by the criterion. Moreover, local contracts are more important for small projects below the WTO-threshold ${ }^{26,27}$.

\section{Conclusion}

The present paper analyzes the effectiveness of social public procurement policy on apprenticeship training in Switzerland. By allowing public purchasers to provide preferential

\footnotetext{
${ }^{26}$ As mentioned above, the "apprenticeship training" criterion does not apply to contracts above a certain threshold.

${ }^{27}$ Unfortunately, no information exists on the share of contracts with firms in a given canton.
} 
treatment for training firms for certain types of public contracts, this procurement policy aims to reach social goals by using public contracts as an incentive for firms to offer training positions.

Based on the analyses of our cross-sectional survey data as well as a robustness check with a difference-in-difference analysis, the results suggest that a public procurement policy can create incentives for non-training firms and therefore generate additional training places. Secondly, training firms do not increase the number of apprenticeship training places as a result of the policy. Thirdly, the "apprenticeship training" criterion primarily affects very small non-training firms and firms in very particular industries where public contracts play an important role. Therefore, the number of additional training places that can be created by such a policy is rather limited. Fourth, we cannot find a negative impact on the quality of these additionally created training places, which suggests that these training positions are not just alibi positions in order to improve chances to gain public contracts.

In conclusion, while such a policy might be beneficial in times of a shortage of training places, the same policy - due to the very specific firms and sectors that can be influenced by this policy can lead to distortions in the training market in times of a shortage of trainees (e.g. because of demographic changes). Therefore a cautious and flexible approach to using such a policy instrument is recommended. 


\section{Appendix}

Table 9: Measures for training quality (only training firms)

\begin{tabular}{lccccc} 
& Mean & Std. Dev. & Min & Max & Observations \\
\hline Number of training hours & 4.55 & 1.64 & 0.33 & 11.11 & 596 \\
Relative productivity compared to a skilled & 0.74 & 0.15 & 0.2 & 1 & 596 \\
\begin{tabular}{l} 
worker in the last year of training \\
\hline
\end{tabular} & & & & & \\
\hline
\end{tabular}




\section{References}

Abadie, Alberto; Drukker, David; Leber Herr, Jane and Imbens, Guido W. (2004). Implementing matching estimators for average treatment effects in Stata. Stata Journal, 4(3): 290-311

Angrist, Joshua and Pischke, Jörn-Steffen (2009). Mostly Harmless Econometrics: An Empiricist's Companion. Princeton University Press, Princeton and Oxford.

Ashenfelter, Orley and Heckman, James (1976). Measuring the Effect of an Antidiscrimination Program. In Evaluating the Labor Market Effects of Social Programs. Ashenfeter and Blum (eds). Princeton: Princeton University Press, 46-84

Bates, Timothy; Williams, Darrell (1996). Do preferential procurement programs benefit minority business? American Economic Review, 86(2): 294-297

Blatter, Marc; Muehlemann, Samuel; Schenker, Samuel (2012). The costs of hiring skilled workers. European Economic Review, 56(1): 20-35

Blatter, Marc; Muehlemann, Samuel; Schenker, Samuel; Wolter, Stefan C. (2015). Hiring costs for skilled workers and the supply of firm-provided training, Oxford Economic Papers, forthcoming.

Chatterji, Aaron K.; Chay, Kenneth Y.; Fairlie, Robert W. (2013). The impact of city contracting set-asides on black self-employment and employment. IZA Discussion Paper No. 7298

Felder, Stefan and Podgorski, Christian (2010). Liberalisierung des öffentlichen Beschaffungswesens in der Schweiz: Auswirkungen auf die Bauwirtschaft. Die Volkswirtschaft, 3(2010).

Goldstein, Morris and Smith, Robert (1976). The estimated impact of the antidiscrimination program aimed at federal contractors. Industrial Labor Relation Review, 29(3): 524-543

Heckman, James J. and Payner, Brook S. (1989). Determining the impact of federal antidiscrimination policy on the economic status of blacks: A study for South Carolina. American Economic Review, 79(1): 138-177

Heckman, James J. and Wolpin, Kenneth (1976). Does the contract compliance program work? An analysis of Chicago data. Industrial Labor Relation Review, 29(3): 544-564

Holzer, Harry and Neumark, David (2000). Assessing affermative action. Journal of Economic Literature, 38(3): 483-568 
Leonard, Jonathan S. (1984a). Antidiscrimination or reverse Discrimination: The impact of changing demographics, Title VII and affirmative action on productivity, Journal of Human Resources, 19(2): 145-174

Leonard, Jonathan S. (1984b). The impact of affirmative action on employment, Journal of Labor Economics, 2(4): 439-463

Leonard, Jonathan S. (1990). The impact of affirmative action regulation and equal employment law on black employment. Journal of Economic Perspectives, 4(4): 47-63

Leuven, Edwin (2005). The economics of private sector training: A survey of the literature. Journal of Economic Surveys, 19(1): 91-111

Marion, Justin (2009). How costly is affirmative action? Government contracting and California's proposition 209. The Review of Economics and Statistics, 91(3): 503-522

McCrudden, Christopher (2004). Using public procurement to achieve social outcomes, Natural Resources Forum, 28(4): 257-267

McCrudden, Christopher (2007). Buying social justice: Equality, government procurment, and legal change. Oxford University Press Inc. New York

Muehlemann, Samuel; Schweri, Juerg; Winkelmann, Rainer; Wolter, Stefan C. (2007). An empirical analysis of the decision to train apprentices. LABOUR: Review of Labour Economics and Industrial Relations, 21(3): 419-441.

Muehlemann, Samuel; Wolter, Stefan C., Wueest, Adrian (2009). Apprenticeship training and the business cycle. Empirical Research in Vocational Education and Training, 1(2), 173186.

Rubin, Donald B. (1974). Estimating causal effects of treatments in randomized and nonrandomized studies. Journal of Educational Psychology, 66, 668-701.

Schweri, Juerg; Mueller, Barbara (2007): Why has the share of training firms declined in Switzerland? Zeitschrift für ArbeitsmarktForschung (ZAF), 40, Iss. 2/3, 149-167.

Westergaard-Nielsen, Niels and Rasmussen, Anders R. (1999). The impact of subsidies on the number of new apprentices. Research in Labour Economics, Vol. 18, 359-375.

Wolter, Stefan C. and Ryan, Paul (2011). Apprenticeship. In: Hanushek, E.A., Machin, S. and Wössmann, L. (Eds.): Handbook of Economics of Education, Vol. 3, S. 521-576. 